\title{
Use of Allogenic Stem Cells for the Prevention of Bone Bridge Formation in Miniature Pigs
}

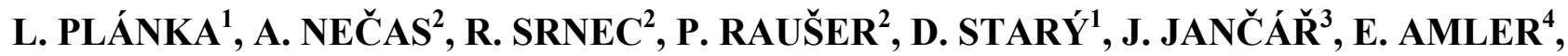 \\ E. FILOVÁ ${ }^{4}$, J. HLUČILOVÁ ${ }^{5}$, L. KŘEN $^{6}$, P. GÁL $^{1}$
}

${ }^{1}$ Clinic of Pediatric Surgery, Orthopedics and Traumatology, the Faculty Hospital Brno,

${ }^{2}$ Department of Surgery and Orthopaedics, Small Animal Clinic, Faculty of Veterinary Medicine, University of Veterinary and Pharmaceutical Sciences Brno, ${ }^{3}$ Institute of Materials Chemistry, Faculty of Chemistry, Brno University of Technology, ${ }^{4}$ Institute of Experimental Medicine of the Academy of Sciences of the Czech Republic, Prague, ${ }^{5}$ Institute of Animal Physiology and Genetics of the Academy of Sciences of the Czech Republic, Prague, ${ }^{6}$ Institute of Pathology and Anatomy, the Faculty Hospital Brno, Czech Republic

Received August 30, 2008

Accepted November 26, 2008

On-line December 17, 2008

\section{Summary}

This study appears from an experiment previously carried out in New Zealand white rabbits. Allogenic mesenchymal stem cells (MSCs) were transplanted into an iatrogenically-created defect in the lateral section of the distal physis of the left femur in 10 miniature pigs. The right femur with the same defect served as a control. To transfer MSCs, a freshly prepared porous scaffold was used, based on collagen and chitosan, constituting a compact tube into which MSCs were implanted. The pigs were euthanized four months after the transplantation. On average, the left femur with transplanted MSCs grew more in length $(0.56 \pm 0.14 \mathrm{~cm})$ compared with right femurs with physeal defect without transplanted MSCs $(0.14 \pm 0.3 \mathrm{~cm})$. The average angular (valgus) deformity of the left femur had an angle point of $0.78^{\circ}$, following measurement and $\mathrm{X}$-ray examination, whereas in the right femur without transplantation it was $3.7^{\circ}$. The initial results indicate that preventive transplantation of MSCs into a physeal defect may prevent valgus deformity formation and probably also reduce disorders of the longitudinal bone growth. This part of our experiment is significant in the effort to advance MSCs application in human medicine by using pig as a model, which is the next step after experimenting on rabbits.

\section{Key words}

Growth plate • Injury • Physis • Limb deformity • Mesenchymal stem cells

\section{Corresponding author}

L. Plánka, KDCHOT, Černopolní 9, 61300 Brno, Czech Republic.

E-mail: Iplanka@seznam.cz

\section{Introduction}

The aim of our study was to verify the capacity of mesenchymal stem cells (MSCs) to repair a partial defect in the distal femoral physis on an experimental model of miniature pigs. A similar experiment preceded the study, using New Zealand white rabbit as a model with promising results (Gál et al. 2007, Plánka et al. 2007). In the majority of similarly-oriented studies, rabbit was chosen as an experimental model (Chen et al. 2003, Ahn et al. 2004), which provided encouraging results. Few cases of MSC transplantation into a physeal defect in pigs have been described in literature so far. There are several works dealing with the positive effects of autologous chondrocyte transplants (Kawabe et al. 1987, Foster et al. 1990, Gál et al. 2002, Filová et al. 2007). This method is a modern modification of a widely used surgical procedure which includes physeal bone bridge resection and filling the post-resection defect with an allogenic fat graft (Langeskiold et al. 1981), a fascia graft or a ligament graft (Janarv et al. 1998), possibly with silicone substitutes. Growth plate injury and results of therapy depended on the age and type of epiphyseolysis.

Instead of a gel scaffold based on Tissucol which was previously applied (Filová et al. 2007, Plánka et al. 2007), we used a MSC transplant and a new 
scaffold in the form of a small porous cylinder consisting of $0.5 \%$ of collagen and $30 \%$ of chitosan (Jančáŕ et al. 2007). The scaffold served as a compact and solid structure which we were able to implant into the created defect by means of the press and fit technique.

Our decision to use allogenic MSCs was based on their potential clinical application. MSCs could be transplanted straight into defects in emergency physeal injuries and bone bridge formation could be prevented in this way. Bone bridge is an adverse complication of physeal fractures in children. In dependence on the location (central, peripheral) of a bone bridge, the affected limb might become shorter or show angular deformity. A combination of both these growth abnormalities might also be observed (Ford and Key 1956, Key and Ford 1958, Campbell et al. 1959). Limb deformity affects mostly medium and large breeds of dogs that are injured before 5 months of age (the most severe deformities develop after Salter-Harris injuries of distal physis of ulna) (Fox, 1984, Henney and Gambardella 1989, Piermattei and Flo 1990). It has been reported that $25-35 \%$ of physeal fractures in humans lead to shortening or deformity of injured bone and that $10 \%$ of these fractures result in functional problems with affected limb (Mizuta et al. 1987, Mann and Rajmaira 1990). Bone deformity is associated with $5-10 \%$ of physeal closures in dogs. In most of these cases, it is necessary to perform corrective osteotomy to restore normal limb functions (Maretta and Schrader 1983).

We expected the femur with partial defect in the distal physis filled with a transplant (MSCs on a scaffold) will not show significant length deformities during its future growth. The other femur served as a control. A separate control group of experimental animals was not established deliberately. By using the other femur of the same animal as a control, we were able to compare two different treatment methods in identical regenerative and healing conditions.

\section{Methods}

The experimental group consisted of eleven miniature pigs which were obtained from certified breeding at the Institute of Animal Physiology and Genetics of the Academy of Sciences of the Czech Republic, Liběchov. At the time of surgery, the age of animals ranged between 2.5 and 3 months and their weight did not vary significantly $(14.4 \pm 3.2 \mathrm{~kg})$.
Preparation of the stem cells

The bone marrow blood was aspirated from os illium (ala osis illi) into the $5 \mathrm{ml}$ syringe with $2 \mathrm{ml}$ Dulbecco's Phosphate Buffered Saline (PBS) with $2 \%$ Fetal Bovine Serum (FBS, StemCell Technologies) and $5 \mathrm{IU}$ heparin/ml connected with a hypodermic needle $(20 \mathrm{G} / 40 \mathrm{~mm})$. Under sterile conditions, the bone marrow blood (about $4 \mathrm{ml}$ ) was deposited over $3 \mathrm{ml}$ of FicollPaque PLUS (StemCell Technologies). After centrifugation at $400 \mathrm{~g}$ for $30 \mathrm{~min}$ at room temperature, the dense gradient separated erythrocytes and granulocytes as a pellet in a bottom part of the tube; mononuclear cells were situated in an opalescent layer between Ficoll and blood plasma. This layer was taken out, washed in a culture medium (see below) and used for propagation under in vitro conditions. The average amount of mononuclear cells from each isolation was $20 \times 10^{6}$ cells. Cell number and viability was analyzed on Vi-CELL (Series Cell Viability Analyzers) and about $90 \%$ of viable cells were detected.

The cells were tested by means of the established positive markers for MSCs (CD29, CD44, CD90, CD105; CD147 has been recently added in several studies). The panel of antibodies used was: anti-CD29 (clone MEM-101A), anti-CD105 (clone MEM 229), antiCD147 (clone MEM-M6/2, Exbio Praha a.s., Prague, Czech Republic), anti-CD44 (clone IM7), anti-CD90 (clone 5E10, BD Biosciences, San Jose, CA, USA), antiCD45 (clone K252 - 1E4, AbD Serotec, Kidlington, UK).

Culture, labeling and differentiation of mesenchymal stem cells

Cells were seeded in $75-\mathrm{cm}^{2}$ tissue culture plastic flasks at a density of approximately $5 \times 10^{5}$ cells $/ \mathrm{cm}^{2}$ and cultured at $37{ }^{\circ} \mathrm{C}$ in humidified atmosphere with $5 \%$ of $\mathrm{CO}_{2}$. The culture medium was $\alpha$-MEM medium (Gibco) supplemented with $10 \%$ FBS (Sigma Aldrich) and gentamycin (50 mg/ml, Sigma Aldrich). After $24 \mathrm{~h}$ of culture, the non-adherent cells were removed and during the subsequent culture (3 weeks) the medium was exchanged every third day. The first colonies of mesenchymal stem cells appeared after 4 to 5 days of culture and the $80 \%$ of confluence was achieved after 10 days of culture. Cells were passaged with trypsin $0.5 \%$ trypsin-EDTA solution (Sigma Aldrich) for $5 \mathrm{~min}$ at $37{ }^{\circ} \mathrm{C}$ and replated in $150 \mathrm{~cm}^{2}$ at a density of $5000-6000$ cells $/ \mathrm{cm}^{2}$.

During the last three days of culture, cells were labeled with nanoparticles of iron oxide (Resovist, 
$0.5 \mathrm{mmol} \mathrm{Fe} / \mathrm{ml}$, Schering). Resovist was added in concentration $1 \mu \mathrm{l} / \mathrm{ml}$ culture medium. For labeling with a fluorescent dye CM-DiI (Molecular Probes) in concentration $5 \mu \mathrm{g} / 2.5 \mathrm{ml} \mathrm{PBS}$, cells were harvested on the day of transplantation, incubated for $5 \mathrm{~min}$ at $37{ }^{\circ} \mathrm{C}$ and for $15 \mathrm{~min}$ at $4{ }^{\circ} \mathrm{C}$. At the end of labeling cells were thoroughly washed in PBS. To induce chondrogenic differentiation (Miura et al. 2002), the labeled cells were given in the differentiation medium composed of $\alpha$-MEM supplemented with $100 \mathrm{ng} / \mathrm{ml}$ recombinant human TGF $\beta_{1}$ (R\&D Systems), $100 \mathrm{nM}$ dexamethasone (Medochemie), $50 \mu \mathrm{g} / \mathrm{ml} \mathrm{L-ascorbic} \mathrm{acid} \mathrm{2-phosphate}$ (Sigma Aldrich), $1 \%$ insulin-transferrin-selenium A (Gibco) for $30 \mathrm{~min}$. Subsequently, the cells were centrifuged at $700 \mathrm{~g}$ for $5 \mathrm{~min}$, and cell pellets were prepared for their deposition in a scaffold.

\section{Scaffold preparation}

Initially, the scaffolds were prepared in the form of flat spongy semi-structures of the required thickness which were cut by surgical instruments to obtain matrices of the desired dimensions and these structures were then implanted with stem cells. Based on in vitro evaluation performed at the Institute of Experimental Medicine of the Academy of Sciences of the Czech Republic, a collagen-based scaffold containing micro- and nanofibers made of chitosan was selected as the most suitable material which meets specific requirements (Koláčná et al. 2007): the required biological features, stability in simulated body environment, biomechanical response and the scaffold behavior at the site of the planned implantation (ex vivo insertion of the scaffold into an iatrogenic defect in articular surface and tests of the mechanical properties of the scaffold on prepared knee joints of pigs in cooperation with the University of Veterinary and Pharmaceutical Sciences Brno and Masaryk University). The lyophilization process was optimized in order to obtain interconnected pores of approximately $100 \mu \mathrm{m}$. With regard to successive testing of the suitable composition of a three-dimensional carrier of MSCs, we can conclude that a small porous cylinder consisting of $0.5 \%$ of collagen and $30 \%$ of chitosan, cross-linked by EDC (1-ethyl-3-(3-dimethylaminopropyl) carbodiimide hydrochloride) and catalyzed by NHS (N-hydroxysuccinimide $98 \%$ ), with chitosan-nanofibersbased structure, seems to be an optimum choice. To facilitate the manipulation during implantation, after lyophilization the cylinder-like substrates were submitted within a 96-well plate.

\section{Surgical procedures}

All animals were intramuscularly administered tiletamine-zolazepam (2 mg/kg, Zoletil 100, Virbac, France), xylazine ( $2 \mathrm{mg} / \mathrm{kg}$, Sedazine, Fort Dodge, USA) in $2 \mathrm{mg} / \mathrm{kg}$ dosing and ketamine $(2 \mathrm{mg} / \mathrm{kg}$, Ketaset, Fort Dodge, USA). All substances were administered together in a single syringe. After the start of sedation in $10 \mathrm{~min}$ after administration, intravenous catheter in the ear vein was instituted and propofol $(1 \mathrm{mg} / \mathrm{kg}$, Propofol $1 \%$, Fresenius, Austria) was administered. Endotracheal tube was inserted in pigs. All pigs were put into right lateral position and connected to the inhalation circle rebreathing system. They were supplied with a mixture of oxygen and air $(1: 1)$ in the amount of $25 \mathrm{ml} / \mathrm{kg} / \mathrm{min}$. All pigs were connected to a vital functions monitor (Datex Cardocap II, USA). The logged values included heart rate (HR), respiratory rate (RR), mean arterial pressure (MAP), hemoglobin saturation by oxygen $\left(\mathrm{SpO}_{2}\right)$ and end-tidal $\mathrm{CO}_{2}$ concentration $\left(\mathrm{ETCO}_{2}\right)$. HR was measured using a three-lead ECG with electrodes located on the chest. MAP was measured using a disposable blood pressure transducer connected to a monitor after calibration. The pressure transducer was connected to the arterial access port (a. auricularis on contralateral ear than venous access) using extension tubing filled with heparinized saline (200 IU heparin/ml, Heparin, Léčiva, Czech Republic). RR and $\mathrm{ETCO}_{2}$ were logged using side-stream with a sensor connected on the tip of endotracheal tube. $\mathrm{SpO}_{2}$ was measured with a sensor connected to the tongue.

After inducing anesthesia, hair was removed from the area of both knee joints of the miniature pig and the skin was washed with soap water and an iodine solution several times. In the final stage of aseptic precautions the operative field was exposed to chlorhexidine and the pig was positioned on the right hip.

Lateral arthrotomy was performed on the left knee joint (Shoja et al. 2002). After visualizing the lateral condyle of distal femur, a $6 \mathrm{~mm}$ screw was used to drill a canal across the growth plate (Colibri battery-driven power tool; SYNTHES, USA). The diameter of the screw was selected with regard to our aim to destroy at least $9 \%$ of the growth zone surface (Janarv et al. 1998). The defect was drilled to a depth of $15 \mathrm{~mm}$ dorsolaterally from the insertion of $m$. extensor digitorum longus. The canal was drilled in dorsomedial direction in order to cause damage to lateral part of distal femoral physis including adjacent parts of epiphysis and metaphysis.

The scaffold with MSCs was inserted into a 
freshly created defect in the physis and its entry was sutured using the edges of periosteum where possible. The stifle joint was lavaged with Ringer lactate solution (Ringer Lactat I.V.Inf., Braun Medical AG). The joint capsule was closed with interrupted suture (PDS 1/0, Ethicon). Subcutaneous layer was closed with continuous suture using 2/0 PDS (Ethicon). The skin was closed with simple interrupted suture using 2/0 Ethilon (Ethicon). Afterwards, a defect in lateral part of distal epiphyseal plate of right femur was created similarly. However, the canal drilled in the condyle was not filled with implant (i.e. the scaffold with autogenous MSCs).

After the surgery, the antagonization of all three anesthetic components was performed using a combination of naloxone $(0.03 \mathrm{mg} / \mathrm{kg}$, INTRENON inj., Léčiva a.s. $)+$ flumazenil $(0.1 \mathrm{mg} / \mathrm{kg}$, ANEXATE, Hoffmann-La Roche Ltd.) + atipamezole $(1.0 \mathrm{mg} / \mathrm{kg}$, ANTISEDAN inj. ad us. vet., Pfizer Animal Health) that was administered intramuscularly. Analgesia in the postoperative period was achieved by the application of carprofen (RIMADYL inj. ad us. vet., Pfizer Animal Health) in the dose of $2 \mathrm{mg} / \mathrm{kg} /$ day for three days after the surgery. Following recovery from the surgery, the animals were allowed to walk freely and weight-bear as tolerated. During the whole study period, the animals were fed, handled and housed according to the principles of welfare (Sýkora et al. 1983). At the end of our experiment (4 months after the surgery), all animals were lege artis euthanized. First, they were put under general anesthesia using intravenous thiopental in the dose of $20 \mathrm{mg} / \mathrm{kg}$. Then they were given intravenous T $61 \mathrm{inj}$. ad us. vet. (Hoechst Roussel Vet.) in the dose of $1 \mathrm{ml}$ pro toto. All procedures were carried out with consent of the Ethical Committee (No. 46613/2003-1020).

\section{Bone length discrepancy and femoral valgus deformity measurements}

Each pig was subjected to radiological examination on the day of transplantation and right after euthanasia. Bone length discrepancy and valgus deformity were measured from radiographs. Measurement of the length of left femur (with physeal defect and transplanted MSCs) and right femur (with physeal defect without transplanted MSCs) was done from radiographs of femur in craniocaudal (CC) projection. Actual length of femur and the angle of valgus deformity of distal femur were measured. The measurements were performed separately by three independent observers. The measured values were averaged to calculate the arithmetic mean.

\section{Histological findings}

Healing of the defect was investigated histologically using hematoxylin and eosin staining. Following the excision of femurs of the euthanized pigs, femoral distal epiphyses were placed in $10 \%$ solution of formalin and stabilized. They were then decalcified in Leavy's solution and gradually dehydrated in solutions with increasing concentration of alcohol to enable embedding them in paraffin. Ultrathin paraffin sections of distal femur $0.1 \mathrm{~mm}$ in thickness were stained with hematoxylin and eosin (HE) and subjected to microscopy. The site of defect in the growth plate of femur was examined histologically.

To verify the formation of developed hyaline cartilage, we used PAS staining (detection of acid mucopolysaccharides found in the intercellular substance of hyaline cartilage) and immunohistochemical staining with an antibody against type-II collagen which is the basis for hyaline cartilage. The origin of chondrocytes located in the physeal defect was confirmed by Pearls method, i.e. the reaction of iron nanoparticles with Berlin blue, and by immunofluorescence with CM-DiI.

\section{Statistical evaluation}

Means and standard deviations were calculated for the length and valgus deformity of right femur (with physeal defect and transplanted MSCs) and left femur (with physeal defect without transplanted MSCs) as well as for differences in length and angular deformities before MSCs transplantation and after euthanasia. The values were statistically analyzed using the Wilcoxon matched-pairs test; STATISTICA (data analysis software system), version 7.1 (StatSoft, Inc. 2005).

\section{Results}

There were no complications during collection of bone marrow blood from iliac wings. In all ten pigs, we successfully cultured MSCs allotransplant in required amounts. In all cases, the required count of MSCs in implant was $2 \times 10^{6}$ cells. There were no anesthesia and post-operative complications in any of the animals. The wounds were healed per primam intentionem. Immunophenotyping indicated more than $95 \%$ of the cells were positive for CD29, CD44 and CD90 and they can be considered homogeneous. The expression of CD105 and CD147 was low.

Results of measurement of femur lengths show that left femurs with damaged distal growth zone and 


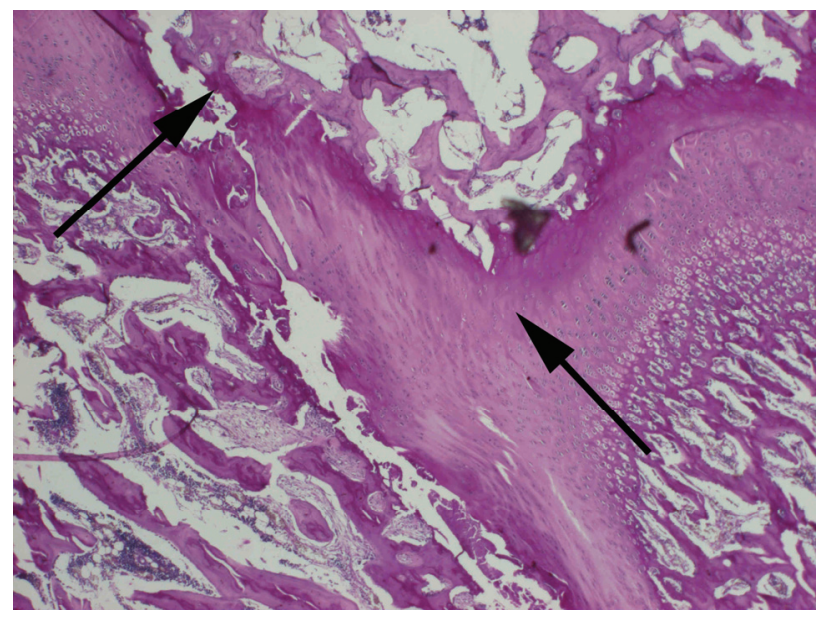

Fig. 1. Histological examination of the left distal femoral physis in miniature pigs after autogenous MSCs transplantation (PAS, 40 $x$ magnification - Pig 8) - arrows indicate the borders of iatrogenic created defect of physis, betwen them is the new cartilagenous tissue.

transplanted MSCs grew more in length $(0.56 \pm 0.14 \mathrm{~cm})$ compared with right femurs with physeal defect without transplanted MSCs $(0.14 \pm 0.3 \mathrm{~cm})$. Angular (valgus) deformity of left femurs with physeal defect and transplanted MSCs was mild $\left(0.78 \pm 0.3^{\circ}\right)$. On the contrary, left femurs with physeal defect without transplanted MSCs showed significant valgus deformity $\left(3.2 \pm 2.5^{\circ}\right)$. Differences in lengths and valgus deformity were statistically significant ( $5 \%$ level of significance, $\mathrm{p}=0.018$ ).

Histological examination revealed that the defect was filled with hyaline cartilage in most cases. Immunohistochemical staining was then performed on hyaline cartilage, using type-II collagen antibodies (90\% positive) and PAS staining (90\% positive) and achieving similar results (Fig. 1). Berlin blue staining detected the presence of rare iron granules in the cytoplasm of newlyformed chondrocytes $(90 \%)$, which explains the origin of cells in the original MSC transplant (Fig. 2). The results of cell examination by immunofluorescence were also largely positive $(80 \%)$, proving that the chondrocytes were differentiated from the transplanted MSCs which had been previously marked with CM-DiI. The bone bridge in iatrogenic-created distal physeal defect of right femurs (control group) was every developed (Fig. 3).

\section{Discussion}

In our previous study, we reported on successful prevention of bone bridge formation and growth arrest using autologous MSC graft transplantation into

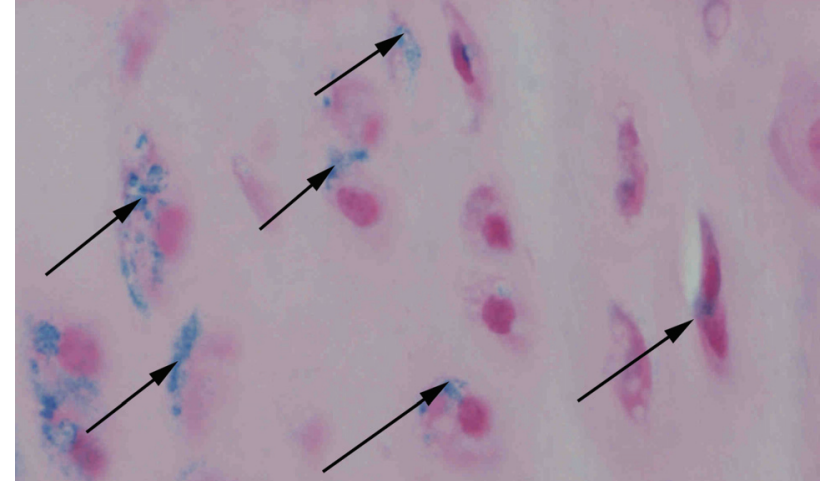

Fig. 2. Resovist granule (arrows) in the chondrocytes cytoplasm (Pig 2) differentiated from MSCs - Pearls reaction (400x).

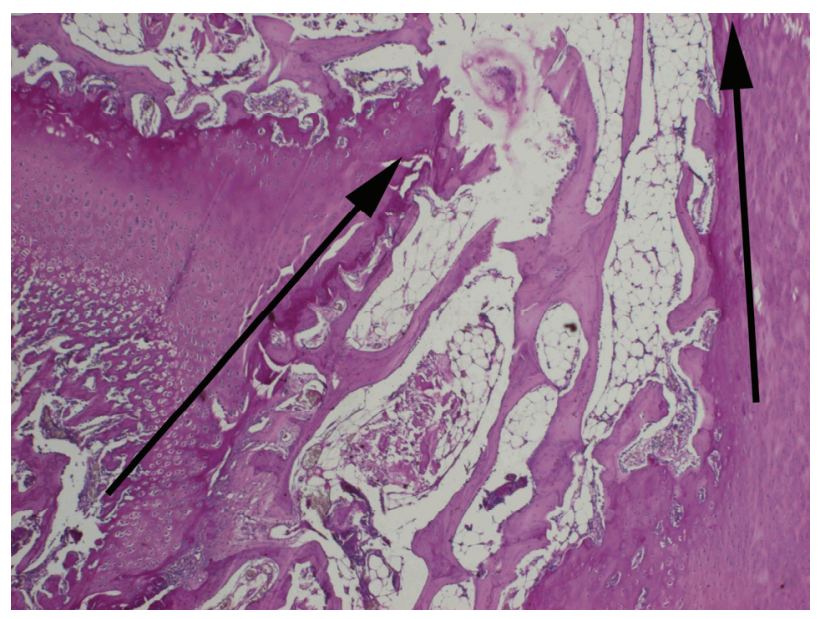

Fig. 3. Histological examination of the right distal femoral physis in miniature pigs after autogenous MSCs transplantation (PAS, 40 $x$ magnification - Pig 7). Arrows indicate the borders of iatrogenic created defect of physis, between them is the bone bridge.

iatrogenically damaged physis in rabbits (Gál et al. 2007, Plánka et al. 2007). The use of a bigger experimental animal is a logical step towards a model with both features and size similar to the human organism and it brings our experiment closer to clinical testing in human medicine. Miniature pig model is reasonable in terms of costs and easy to maintain. We obtained animals from certified breeding at the Institute of Animal Physiology and Genetics in Liběchov, the only institution of this kind in the Czech Republic. The fact that FBS is necessary for culturing MSCs prior to the transplantation is the only impediment to clinical testing.

The collection of bone marrow and the isolation of stem cells are prerequisites for success. The obtained blood samples and the isolated cells were, in addition to the previously described procedure, subjected to other typing methods. We selected the best-defined cell colony based on the expression of positive $\mathrm{CD}$ markers and the 
absence of negative CD markers. The cultured cells were tested by means of the established positive markers for MSCs (CD29, CD44, CD90, CD105; CD147 has been recently added in several studies). Low expression, possibly lack of expression, in case of CD105 and CD147 might be explained by their tendency to reflect with increased sensitivity the contemporary state of the cultured cells. This is particularly the case of incipient spontaneous differentiation which can be induced by a number of external factors, such as a higher cell density and cell interaction.

To achieve results which would be valid and clear, it was essential to choose such a growth plate within the skeleton that has significant growth potential and contributes to bone growth. Taking these criteria into consideration, the selected portion of the physis, i.e. the growth zone of distal epiphysis of femur, seems to be an optimum choice as it is responsible for $70 \%$ of longitudinal growth of femur and it is the largest bone in miniature pigs. The lateral condyle is easily accessible in terms of surgery, facilitating a quick surgical procedure (reducing the time of general anesthesia) and resulting in low occurrence of postoperative complications.

Cultured MSCs were stimulated to differentiate towards chondrocytes in $\alpha$-MEM medium with the supplement of human recombinant TGF- $\beta 1$ (Miura et al. 2002). The culture medium was also supplemented with $1 \%$ ITS, dexamethasone and ascorbate-2-phosphate which are commonly used ingredients of culture and differentiation medium (Quintavalla et al. 2002, Indrawattana et al. 2004, Li et al. 2005, Lisignoli et al. 2005). In some studies, MSCs were successfully differentiated using TGF- $\beta 3$ (Chen et al. 2004, Lee et al. 2004), in some cases combined with BMP-6 or IGF-1 (Indrawattana et al. 2004). As the role of these factors and accurate timing of their application is not completely clear, we differentiated the MSCs using the TGF- $\beta 1$ alone, the application of which is a commonly recognized method of influencing differentiation of mesenchymal stem cells toward chondrocytes (Hui et al. 2005, Li et al. 2005, Lisignoli et al. 2005). In our study, we used TGF- $\beta 1$ (in concentration of $100 \mathrm{ng} / \mathrm{ml}$ ) to affect MSCs in medium for $30 \mathrm{~min}$ (Miura et al. 2002). Today, higher concentrations of TGF- $\beta 1$ are recommended (Lisignoli et al. 2005). Hui et al. (2005) used TGF- $\beta 1$ even in concentration of $1000 \mathrm{ng} / \mathrm{ml}$.

In our previous study, a different type of scaffold, based on tissue adhesive $(0.12 \mathrm{ml}$ solution of human protein for Tissucol, Tissucol®Kit Baxter), was used. This scaffold had a gel structure and following its transplantation into an iatrogenic defect in the lateral section of the distal growth zone of femur, it was necessary to close the external entry of the defect using bioceramics. It was the only way to prevent the scaffold and MSCs from traveling outside the defect. In this study, we used a solid scaffold based on collagen and chitosan which retained its shape of a compact cylinder after implanting it with MSCs and we were able to fix it in the created defect by means of the press and fit technique. In the future, the exact shaped scaffold after the MR can be created (Krupa et al. 2007).

By definition the method to create the bone bridge iatrogenically, we took the results of our previous study (Gál et al. 2002, Varga et al. 2007) and the experimental study of Janarv et al. (1998). We believed that this tried and tested method, causing damage to more than $9 \%$ of the growth plate area, was highly confidental. For this reason, we used a screw of $6 \mathrm{~mm}$ in diameter.

The proper clinical verification of the impact of preventive MSC transplantation into the defect in femoral distal physis on longitudinal bone growth and on the degree of incurred valgus deformity was based on measuring these quantities from radiographs of femur in craniocaudal projection. The femoral length was measured as the distance between the femur head tip and the tangent of the most distant point of femoral condyle (Janarv et al. 1998), while the degree of valgus deformity of distal femur was measured as the angle between the long axis of the bone and the vertical to the tangent connecting femoral condyles. We expected that the left femur with a defect in the lateral section of the growth plate will be, due to preventive transplantation of MSCs, longer and less valgus deformed (or entirely without valgus deformity) than the right femur with the same physis defect, but without MSC transplantation (i.e. a bone bridge bridging the physis). This hypothesis was proven by measurement performed by three independent observers.

Radiological examination is readily accessible and allows determining with a relatively high accuracy both the length of the x-rayed bone and its possible angular deformity. The method of measuring the femur length was based on the original study of Janarv et al. (1998), whereas the measuring of the extent of valgus deformity had been consulted with specialists on descriptive geometry for the needs of our earlier studies (Gál et al. 2007, Plánka et al. 2007).

Histological examination of prepared 
specimens was carried out by a pathologist, using staining with hematoxylin and eosin. The tissue filling the iatrogenically-induced defect was examined under a microscope. In case of discovering cartilage, a macroscopic view was applied to determine whether it was hyaline cartilage or fibrocartilage. Potential signs of an immune reaction against the transplant observed in the body of the experimental animal (Graft versus Host Disease) were also evaluated. The site of defect filling was checked for necrosis and sequestration and lymphocyte infiltration was assessed. We can conclude that no such signs were found in any of the experimental animals. To detect hyaline cartilage properties, immunohistochemical examination for type-II collagen antibodies was chosen with regard to available literature. All similarly-oriented studies consider this examination as a crucial indicator confirming the positive outcome of treatment. We also used PAS staining which gives a specific color reaction with both neutral and acid muco-polysaccharides found in the intercellular substance of the cartilage. Some authors refer to alcian blue staining which, however, stains only acid mucopolysaccharides. Safranin O staining and type-X collagen antibodies were not opted because the above mentioned methods are sufficient to verify the results of our experiment and since the two methods are rather costly.

The results of Pearls reaction were positive, showing the detected iron particles colored in blue (combined with Berlin blue). Considering the length of observation period (from surgery until euthanization), we expected that the originally phagocyted grains of iron nanoparticles (Resovist) will be hardly detectable as they are subject to gradual division into daughter cells. The aggregation of the blue pigment might indicate false positivity, for example in the case when the death of the original cells occurs and they are phagocyted by the macrophages. However, our cells with noticeable grains of iron obviously merged with viable cartilaginous tissue without signs of necrosis. To further confirm their origin, we used immunofluorescence with CM-DiI which is deposited on the membrane of MSCs during the first staining. This method of staining is also subjected to quick division into daughter cells and thus the detection of the pigment using a fluorescence microscope was only localized.

The results of this experimental study in pigs confirmed our hypothesis that transplantation of autologous mesenchymal stem cells into experimental physeal defect can prevent bone bridge formation and thereby bone shortening and angular (valgus) deformity. The procedure can promote healing of damaged growth plate by differentiation of transplanted mesenchymal stem cells into chondrocytes.

\section{Conclusions}

The MSCs which we transplanted differentiated in vivo into functional chondrocytes of the growth plate in the form of hyaline cartilage. Preventive transplantation of MSCs in our experiment prevented development of angular deformity and eliminated growth arrest of femur in physeal injuries in pigs.

\section{Conflict of Interest}

There is no conflict of interest.

\section{Acknowledgements}

This work was supported by the Ministry of Health of the Czech Republic (Research Projects of IGA MZ CR NR9296-2/2007) and Ministry of Education, Youth and Sport of the Czech Republic (NPV II 2B06130).

\section{References}

AHN JI, CANALE TS, BUTLER SD, HASTY KA: Stem cell repair of physeal cartilage. J Orthop Res 22: 1215-1221, 2004.

CAMPBELL CJ, GRISOLIA A, ZANCONATO G: The effects produced in the cartilaginous epiphyseal plate of immature dogs by experimental surgical traumata. J Bone Joint Surg 41: 1221-1242, 1959.

CHEN F, HUI JHP, CHAN WK, LEE EH: Cultured mesenchymal stem cell transfers in the treatment of partial growth arrest. J Pediatr Orthop 23: 425-429, 2003.

CHEN G, LIU D, TADOKORO M, HIROCHIKA R, OHGUSHI H, TATEISHI T, TANAKA J: Chondrogenic differentiation of human mesenchymal stem cells cultured in cobweb-like biodegradable scaffold. Biochem Biophys Res Commun 322: 50-55, 2004. 
FILOVÁ E, RAMPICHOVÁ M, HANDL M, LYTVYNETS A, HALOUZKA R, USVALD D, HLUČILOVÁ J, PROCHÁZKA R, DEZORTOVÁ M, ROLENCOVÁ E, TRČ T, ŠŤASTNÝ E, KOLÁČNÁ L, HÁJEK M, MOTLÍK J, AMLER E: Composite hyaluronate-type I collagen-fibrin scaffold in the therapy of osteochondral defects in miniature pigs Physiol Res 56 (Suppl 1): S5-S16, 2007.

FORD LT, KEY JA: A study of experimental trauma to the distal femoral epiphysis in rabbits. $J$ Bone Joint Surg $\mathbf{3 8}$ : 84-92, 1956.

FOSTER BK, HANSEN AL, GIBSON GJ, HOPWOOD JJ, BINNS GF, WIEBKIN OW: Reimplantation of growth plate chondrocytes into growth plate defects in sheep. J Orthop Res 8: 555-564, 1990.

GÁL P, NEČAS A, ADLER J, TEYSCHL O, FABIÁN P, BIBROVÁ Š: Transplantation of the autogenous chondrocyte graft to physeal defects: an experimental study in pigs. Acta Vet Brno 71: 327-332, 2002.

GÁL P, NEČAS A, PLÁNKA L, KECOVÁ H, KŘEN L, KRUPA P, HLUČILOVÁ J, USVALD D: Chondrocytic potential of allogenic mesenchymal stem cells transplanted without immunosuppression to regenerate physeal defect in rabbits. Acta Vet Brno 76: 265-275, 2007.

HENNEY LH, GAMBARDELLA PC: Premature closure of the ulnar physis in the dog: a retrospective clinical study. $J$ Am Anim Hosp 25: 573, 1989.

HUI JHP, LI L, TEO YH, OUYANG HW, LEE EH: Comparative study of the ability of mesenchymal stem cells derived from bone marrow, periosteum, and adipose tissue in treatment of partial growth arrest in rabbit. Tissue Engn 11: 904-912, 2005.

INDRAWATTANA N, CHEN G, TADOKORO M, SHANN LH, OHGUSHI H, TATEISHI T, TANAKA J, BUNYARATVEJ A: Growth factor combination for chondrogenic induction from human mesenchymal stem cell. Biochem Biophys Res Commun 320: 914 -919, 2004.

JANARV PM, WIKSTRÖM B, HIRSCH G: The influence of transphyseal drilling and tendon grafting on bone growth: an experimental study in the rabbit. J Pediatr Orthop 18: 149-154, 1998.

JANČÁŘ J, SLOVÍKOVÁ A, AMLER E, KRUPA P, KECOVÁ H, PLÁNKA L, GÁL P, NEČAS A: Mechanical response of porous scaffolds for cartilage engineering. Physiol Res 56 (Suppl 1): S17-S25, 2007.

JANOVEC M, JOCHYMEK J: The importance of age in patients for the subsequent state of the growth plate cartilage lengthened by distraction epiphysiolysis (in Czech). Acta Chir Orth Traumat Cech 60: 325-332, 1993.

KAWABE N, EHRLICH MG, MANKIN HJ. Growth plate reconstruction using chondrocyte allograft transplants. J Pediatr Orthop 7: 381-388, 1987.

KEY JA, FORD LT: A study of experimental trauma to the distal femoral epiphysis in rabbits. $J$ Bone Joint Surg 40: 887-896, 1958.

KOLÁČNÁ L, BAKEŠOVÁ J, VARGA F, KOŠŤÁKOVÁ E, LUKÁŠ D, AMLER E, PELOUCH V: Biochemical and biophysical aspects of collagen nanostructure in the extracellular matrix. Physiol Res 56 (Suppl 1): S51-S60, 2007. A study of experimental trauma to the distal femoral epiphysis in rabbits.

KRUPA P, KRŠEK P, JAVORNÍK M, DOSTÁL O, SRNEC R, USVALD D, PROKŠ P, KECOVÁ H, AMLER E, JANČÁŘ J, GÁL P, PLÁNKA L, NEČAS A: Use of 3D geometry modeling of osteochondrosis-like iatrogenic lesions as a template for press-and-fit scaffold seeded with mesenchymal stem cells. Physiol Res $\mathbf{5 6}$ (Suppl 1): S107-S114, 2007.

LANGENSKIÖLD A: An operation for partial closure of an apophyseal plate in children, and its experimental basis. Bone Joint Surg [Br] 57: 325-330, 1975.

LEE JW, KIM YH, KIM SH, HAN SH, HAHN SB: Chondrogenic differentiation of mesenchymal stem cells and its clinical applications. Yonsei Med J 45: 41-47, 2004.

LI WJ, TULI R, OKAFOR C, DERFOUL A, DANIELSON KG, HALL DJ, TUAN RS: A three-dimensional nanofibrous scaffold for cartilage tissue engineering using human mesenchymal stem cells. Biomaterials 26: 599-609, 2005.

LISIGNOLI G, CRISTINO S, PIACENTINI A, TONEGUZZI S, GROSSI F, CAVALLO C, ZINI N, SOLIMANDO L, NARALDI NM, FICCHINI A: Cellular et molecular events dutiny chondrogenesis of human mesenchymalstromal cells grown in three-dimensional hyaluronan based scaffold. Biomaterials 26: 56775686, 2005. 
MANN DC, RAJMAIRA S: Distribution of physeal and nonphyseal fractures in 2650 long-bone fractures in children aged 0-16 years. J Pediatr Orthop 10: 713, 1990.

MARETTA SM, SCHRADER SC: Physeal injuries in the dog: A review of 135 cases. J Am Vet Med Assoc 182: 708$710,1983$.

MIURA Y, PARVIZI J, FITZSIMMONS JS, O'DRISCOLL SW: Brief exposure to high-dose transforming growth factor-beta1 enhances periosteal chondrogenesis in vitro: a preliminary report. J Bone Joint Surg 84-A: 793$799,2002$.

MIZUTA T, BENSON WM, FOSTER BK: Statistical analysis of the incidence of physeai injuries. J Pediatr Orthop 7: 518-523, 1987.

PIERMATTEI DL, FLO GL, DECAMP C: Handbook of Small Animal Orthopaedics and Fracture Treatment. Elsevier, Philadelphia, 1990, pp 681-682.

PLÁNKA L, NEČAS A, GÁL P, KECOVÁ H, FILOVÁ E, KŘEN L, KRUPA P: Prevention of bone bridge formation using transplantation of the autogenous mesenchymal stem cells to physeal defects: An experimental study in rabbits. Acta Vet Brno 76: 253- 263, 2007.

QUINTAVALLA J, UZIEL-FUSI S, YIN J, BOEHNLEIN E, PASTOR G, BLANCUZZI SINGH HN, KRAUS KH, O'BYRNE E, PELLAS TC: Fluorescently labeled mesenchymal stem cells (MSCs) maintain multilineage potential and can be detected following implantation into articular cartilage defects. Biomaterials 23: 109-119, 2002.

SHOJA A, OPATÍK J, ŠTEFANCO V, BDŽOCH M, KOKAVEC M: Arthroscopic lateral liberalization and bipartite patella (in Slovak). Slovenský lekár 9-10: 368-370, 2002.

SÝKORA I, DYNTEROVÁ A, HOLDA J, MARHAN O: Laboratory Animal Breeding (in Czech). Institut výchovy a vzdělávání MZVž, Praha, 1983.

VARGA E, DRŽÍK M, HANDL M, CHLPÍK J, KOS P, FILOVÁ E, RAMPICHOVÁ M, TRČ T, AMLER E: Biochemical characterization of cartilages by a novel approach of blunt impact testing. Physiol Res 56 (Suppl 1): S61-S68, 2007. 